\title{
Alfonso X de Castilla, o la sabiduría como herramienta del poder
}

\author{
Daniel GREGORIO \\ Universidad de Valenciennes
}

A Fernando. In Memoriam

\begin{abstract}
RESUMEN. Al calificar a Alfonso X de sabio, tanto sus contemporáneos como la Historia le otorgan una personalidad diferente a la de los demás monarcas. Sin abandonar el clásico papel del monarca defensor de la Iglesia o del rey conquistador, Alfonso $\mathrm{X}$ va a esforzarse por desarrollar un programa didáctico y político que hace de él un rey diferente. Inspirado por Dios, que le habría otorgado más facultades intelectuales y humanas que a los demás monarcas, Alfonso X se presenta como la antítesis del tirano, favoreciendo el desarrollo cultural, político y social de su reino. Puesto que la dignidad real es un don de Dios, el rey castellano va a rebasar los límites de la política para asociar su gobierno a una auténtica labor pastoral, expresada por la variedad temática de sus obras y la íntima relación que pretende mantener con los poderes celestiales. Alfonso X, como sabio, se presenta entonces como un monarca completo, capaz de actuar tanto en lo temporal como en lo espiritual, personificando así la imagen de rey-sacerdote.

Palabras clave: Alfonso X, sabiduría, cantigas, política, monarquía, tiranía, astromagia.

RÉSUMÉ. En qualifiant Alphonse $\mathrm{X}$ de sage, ses contemporains et l'Histoire lui octroient une personnalité différente de celle des autres monarques. Sans abandonner le rôle classique du souverain défenseur de l'Église ou du roi conquérant, Alphonse $\mathrm{X}$ va s'efforcer de développer un programme didactique et politique qui fait de lui un roi différent. Inspiré par Dieu, qui lui aurait donné plus de facultés intellectuelles et humaines qu'aux autres monarques, Alphonse $\mathrm{X}$ se présente comme l'antithèse du tyran, en favorisant le développement culturel, politique et social de son royaume. Puisque la dignité royale est un don de Dieu, le roi castillan assume son labeur pastoral de chef du royaume, sous la protection des pouvoirs célestes, en produisant des œuvres à la thématique variée. Alphonse $\mathrm{X}$, en tant que sage, se présente alors comme un monarque complet, capable d'agir aussi bien dans le temporel que dans le spirituel, et il personnifie ainsi l'image du roi-prêtre.
\end{abstract}

Mots clés: Alphonse $\mathrm{X}$, sagesse, cantigas, politique, monarchie, tyrannie, astromagie.

Rey sabio, dos palabras sencillas, asociadas casi de forma exclusiva a Alfonso $X$ de Castilla. Parecen bastarse a sí mismas para expresar una realidad política y social del medievo hispánico, y en cierto modo así es, aunque es necesario detenerse un momento para saber exactamente qué estamos diciendo al calificar al monarca castellano de rey sabio, y sobre todo, por qué lo hacemos.

El primer escollo lo encontramos precisamente en el hecho de que, a Alfonso $\mathrm{X}$, no siempre se le ha calificado de sabio. En algunas ocasiones se le ha denominado Alfonso el Astrólogo y en otras Alfonso el 
Grande ${ }^{1}$, aunque en otras, como lo recuerda Robert Burns, se le ha negado cualquier capacidad intelectual real por considerársele un pésimo gobernante ${ }^{2}$. Nos encontramos con dos apelativos que, sin estar realmente en contradicción, parecen referirse a dos facetas muy diferentes de la vida del rey. El primero no tiene nada que ver, en teoría, con la práctica de la política y el segundo nos remite, aunque sólo sea por una asociación automática y en absoluto justificada, a acciones guerreras personalizadas en la Antigüedad por Alejandro de Macedonia y en tiempos más cercanos por Catalina II de Rusia. A ello viene a añadirse une elemento suplementario y es que la noción de sabio ha sido traducida de distintas maneras fuera de España. En el hispanismo anglosajón se alternan los términos de wise y learned, de la misma manera que en el francófono se usan los términos de sage y savant. Esta doble apreciación podría traducirse en castellano antiguo por los vocablos sabio y sabidor ${ }^{3}$.

Es costumbre adjudicar a cada soberano un epíteto que subraya algún rasgo de su política o de su personalidad. Es una forma de humanizar al rey, de sacarlo de una lista ordinal, y al mismo tiempo de asentar una propaganda, una imagen oficial del monarca y de la realeza en general. De ahí que Alfonso X destaque, puesto que los

\footnotetext{
${ }^{1}$ F. MÁrquez VillanUeVA, El concepto cultural alfonsi, Barcelona, 2004, p. 196-197.

${ }^{2}$ R. BURNS, Emperor of Culture, Alonso X the Learned of Castille and his thirteenth-century Renaissance, Filadelfia, 1990.

${ }^{3}$ A. RUCQUOI, «El rey sabio: cultura y poder en la monarquía medieval castellana» in H. GARRIDO, Repoblación y reconquista, Actas del III Curso de cultura medieval, Centros de Estudios del Románico, 1993, p. 79: «El sabio, en este contexto, no puede ser, en ningún caso, confundido don el letrado, el sabidor dirá Alfonso $X$, aquél que posee un saber escrito, ni es el filósofo que intenta comprender los movimientos y las causas hasta llegar a la causa primera, al motor primitivo que se piensa a sí mismo».
}

dos temas clásicos asociados a los soberanos son, por una parte, la bondad y la espiritualidad, atribuidas a Fernando III de Castilla, a Luis IX de Francia, a Esteban I de Hungría o al infante Fernando de Portugal $\mathrm{y}$, por otra, la bravura guerrera estrechamente vinculada con los personajes de Guillermo el Conquistador, Jaime I el Conquistador, Alfonso I el Batallador, o Sancho el Bravo. Como veremos, no es que se catalogue de forma diferente a Alfonso $X$, sino que al apodarlo el sabio se está sublimando su persona, poniéndola por encima de los demás atribuyéndole todas las cualidades de los demás monarcas.

Por supuesto son varios los soberanos que han sido representados como sabios, y el primero de ellos sería el rey Salomón, paradigma de todos los monarcas. Pero son muy pocos los que comparten el mismo apodo con Alfonso $X$ de Castilla. Entre estos últimos podemos citar a Sancho VI de Navarra, y a Carlos V de Francia. No es que los demás monarcas no emprendieran políticas similares a las de estos reyes, de la misma forma que estos no rechazaban programas y proyectos idénticos a los de los reyes más guerreros, pero había algo que los diferenciaba entre sí. A modo de ejemplo, citemos a Federico II Hohenstaufen, con el que a menudo se compara a Alfonso $X$. Ambos monarcas promovieron proyectos culturales y legislativos de gran envergadura, y ambos organizaron cruzadas, de mayor o menor calado, contra el enemigo religioso. Pero a Federico II, pese a reconocerlo como gran mecenas, no se le apodó el sabio.

Empecemos pues por intentar comprender lo que podía ser la sabiduría, tal y como se la entendía en la Edad Media.

Cuando evocamos el personaje de un sabio, fácilmente se nos vienen a la mente imágenes, más o menos estereotipadas, de un hombre barbudo, entrado en años y a 
veces algo despistado. Seguramente el origen de dichos estereotipos se encuentra en la comunidad formada por los Siete Sabios de Grecia, cuya representación ha ido evolucionando con el tiempo, desde el mosaico expuesto hoy en día en el Museo Nacional de Arte Romano de Mérida hasta el Atlas Coelestis de Andreas Cellarius del siglo XVIII. No son sólo los nombres de estos sabios los que han cambiado, sino que sus actividades también han ido evolucionando con el tiempo. Se nos presentan así discutiendo animadamente o escudriñando el mundo con aparejos de diversa índole. La discusión hablada, la transmisión de las ideas y la observación parecen pues ser dos elementos básicos de la sabiduría. Mientras los personajes personalizan la capacidad intelectual del raciocinio y la necesidad de compartir y confrontar ideas, los aparatos utilizados nos indican un intento de medir o de descubrir el mundo circundante. El sabio parece pues trabajar sobre el mundo y por lo tanto difícilmente podría abstraerse de la realidad cotidiana.

La mejor definición de lo que es la sabiduría nos la proporciona sin duda Isidoro de Sevilla en sus Etimologías ${ }^{4}$. Según él, «sapiens (sabio) es una palabra derivada de sapor (sabor) porque así como el gusto es apropiado para discernir el sabor de los alimentos, así el sabio se encuentra capacitado para apreciar las cosas y sus causas; porque conoce cada una de ellas y las enjuicia con criterio de verdad» ${ }^{5}$. Con esta frase el santo sevillano sintetiza todos los elementos humanos que pueden asociarse a la sabiduría. Ésta se basa en el conocimiento, y en la capacidad de apreciar o enjuiciar las cosas, para conocer la verdad. La sabiduría se presenta pues como un rasgo personal

\footnotetext{
${ }^{4}$ ISIDORO DE SEVILla, Etimologías, edición de J. Oroz Reta y M. Marcos CASQuero, 2 volúmenes, Madrid, 2000.

${ }^{5}$ Etimologías, X, 240.
}

que permite al individuo percibir y comprender los entresijos de una situación determinada. Todo ello correspondería a la faceta de discusión y cálculo que indicábamos antes, y desde luego aparta cualquier noción de abstracción del mundo, puesto que el mundo es justamente el objeto de estudio del sabio.

Se va perfilando así un contexto social, filosófico e intelectual que tomará cuerpo en los siglos XII y XIII y que se caracteriza por «el papel esencial que [se] concede al factor racional, a la búsqueda de las rationes necessariae de san Anselmo, merced al entendimiento o capacidad de conocer que posee el hombre. A través del estudio, se crean entonces el trivium y el quadrivium, se desarrolla la razón humana y su capacidad de entendimiento, el intellectus, le lleva a la sapientia que es conocimiento de lo divino, y por eso unificador de la existencia humana: la sapientia es scientia ordina$t a$, dirá santo Tomás de Aquino» ${ }^{6}$.

Nos encontramos ya con los conceptos básicos del intelecto y del entendimiento, que van a quedar íntimamente ligados con el de sabiduría. Pero a ellos viene a añadirse una dimensión espiritual suplementaria, puesto que «sabio viene de sabiduría, porque primero existió la sabiduría» ${ }^{7}$. Esta última queda pues definida como un elemento autónomo que existe por sí mismo y que genera a los sabios. Es exactamente la situación descrita en el libro de los Proverbios (8, 22-36), donde la Sabiduría toma la palabra $\mathrm{y}$ nos dice:

«Desde la eternidad fui establecida, desde los orígenes antes que la tierra fuese. Antes que los abismos fui engendrada yo; antes que fuesen las fuentes de abundantes aguas, antes que los montes fuesen cimentados, (...) Oídme pues hijos míos, bienaventurado el

\footnotetext{
${ }^{6}$ A. RUCQUOI, ob. cit., p. 78.

${ }^{7}$ Etimologías, X, 1.
} 
que sigue mis caminos. Escuchad la instrucción y sed sabios y no lo menospreciéis».

La sabiduría no es una característica intrínsecamente humana, es algo que se puede alcanzar pero que no pertenece realmente al ser humano. Ello nos lo confirma Alfonso X, en el prólogo del Libro de las Cruces, al afirmar que «el ángel es más alto y más noble que el hombre, por su gran entendimiento y por su gran saber que Dios le dio. Así el hombre en quien Dios quiso poner seso y entendimiento es más alto $\mathrm{y}$ más noble entre todos los hombres» ${ }^{8}$.

El rey castellano, además de describir una jerarquía humana y celestial, nos indica que la sabiduría pertenece sin lugar a dudas al campo teológico, lo que tendrá implicaciones políticas y filosóficas que no pueden soslayarse, puesto que, a la postre, «el sabio es santo» ${ }^{9}$. Por supuesto, Alfonso $X$ no niega la existencia de una nobleza de linaje, que de hecho tendrá su importancia en la continuidad histórica de la realeza, pero también nos está indicando que la auténtica superioridad de un individuo no reside tanto en sus acciones guerreras, como en su seso y su entendimiento, otorgados por Dios para actuar con justicia. Como lo indicó en su día Denis Menjot, se puede pensar que «la imagen del rey-guerrero no es exaltada, puesto que las acciones militares son consideradas como actos fáciles porque son instintivos. Se privilegia la reflexión sobre la acción brutal, la prudencia y la búsqueda de la paz sobre la hazaña y la violencia gratuitas» ${ }^{10}$. Por ello, el rey castellano afirma que en él, «Dios puso seso y entendimiento $\mathrm{y}$ saber sobre todos los príncipes de su tiempo, leyendo por diversos libros de sabios, por alumbramiento

\footnotetext{
${ }^{8}$ AlfONSO X, Libro de las cruces, Madrid, Biblioteca Nacional, Ms. 9294, fol $2 \mathrm{r}^{\circ}$.

${ }^{9}$ A. RUCQUOI, ob. cit., p. 81.

${ }^{10}$ D. MENJOT, Dominar y controlar en Castilla en la Edad Media, Málaga, 2003, p. 263.
}

que tuvo de la gracia de Dios de quien vienen todos los bienes, siempre se esforzó de alumbrar y de avivar los saberes que eran perdidos al tiempo que Dios le mandó reinar en la tierra» ${ }^{11}$.

Nos encontramos aquí con una auténtica profesión de fe, es la motivación esencial del programa político del rey castellano resumida en unas breves palabras. Además de plantear le superioridad intelectual por encima de la actividad guerrera, Alfonso $X$ recalca que la sabiduría y el conocimiento no son fáciles de adquirir y de conservar, ya que requieren un esfuerzo constante de estudio y de lectura que no son incompatibles con las obligaciones políticas del monarca. La consecuencia más directa es que, al recibir más seso y entendimiento que los demás monarcas, en una jerarquía político-espiritual en la que el entendimiento acerca el hombre a Dios y a sus ángeles, Alfonso X se presenta ya como el más noble de los reyes. En un plano puramente político, ello parece designarlo como mejor candidato a la corona imperial, que intentará obtener durante casi veinticinco años. Por otra parte, su insistencia al afirmar que se esforzó por alumbrar y avivar los saberes, se inserta perfectamente en la visión que tenía el monarca de lo que tenía que ser un buen soberano. No es que Alfonso $\mathrm{X}$ abandone las tradicionales obligaciones espirituales y guerreras que evocábamos antes, pero parece añadir una dimensión suplementaria al ejercicio del gobierno, considerado como una misión divina en la que se aúnan las obligaciones políticas del rey y su tarea de divulgación de los conocimientos pasados.

Así, la reflexión sobre lo que es la sabiduría, nos obliga a detenernos sobre lo que son esas obligaciones del monarca.

\footnotetext{
${ }^{11}$ Libro de las cruces, fol. $2 \mathrm{r}^{\circ}$.
} 
El papel del monarca ha quedado establecido a lo largo de los siglos en diversos escritos, tanto políticos como filosóficos, de entre los cuales, para el siglo XIII, puede destacar la Monarquía de santo Tomás de Aquino. Por supuesto el papel y la misión del rey fueron objeto de reflexiones anteriores, e incluso de un intento de explicación sociolingüística, como lo demuestran la Etimologías de Isidoro de Sevilla.

Tras indicar que no siempre se pueden explicar las palabras por la etimología, puesto que a veces se atribuyen nombres de forma caprichosa y sin relación con la naturaleza de las cosas referidas, el santo sevillano nos indica que la palabra rey (rex) proviene de la noción de regir (regere) y de actuar correctamente (recte agere) ${ }^{12}$. De ahí que el rey se presente como un personaje que actúa correctamente, con rectitud y que por lo tanto sus palabras y sus ademanes han de expresar la acción ponderada y justa que le corresponde.

Alfonso $\mathrm{X}$ hace suyos estos preceptos y por ello en sus Siete Partidas insiste en la educación que el príncipe ha de recibir para ser un buen rey ${ }^{13} \mathrm{y}$ en el comportamiento que ha de tener una vez coronado ${ }^{14}$. La legislación alfonsí establece todo un programa educativo para el príncipe, que debe oír y leer narraciones y buenas palabras que le sirvan de modelo. Entre las lecturas que debe seguir el heredero de la corona se encuentran seguramente los numerosos espejos de príncipes, es decir, composiciones que contenían lecciones de moralidad y prudencia para los gobernantes. Son relatos o crónicas ejemplares que proponen al dirigente pautas para cumplir su papel. De entre ellos tal vez los más conocidos sean el Libro de los doce sabios, los Bocados de Oro y

12 Etimologías, I, 29, 3.

${ }^{13}$ Alfonso X, Siete Partidas, Ms. I-766, Biblioteca Nacional de Madrid, II, 7, 4 y siguientes, fol. $82 \mathrm{v}^{\circ}-84 \mathrm{r}^{\circ}$.

${ }^{14}$ Ibid., II, 9. por supuesto el Secretum Secretorum o el Poridat de las Poridades. A ellos se añade también el Calila e Dimna, conjunto de fábulas que establece cierta filosofía y referentes morales dignos de ser seguidos por el monarca y cuya traducción fue promovida por Alfonso $X^{15}$.

Es interesante ver que hoy en día se sigue atribuyendo a la monarquía medieval esa característica de acción ponderada y personalidad comedida. Como lo indicó en su día Georges Duby, la Edad Media perpetuó la figura del rey como modelo de la perfección terrenal que representaba el equilibrio de la estructura universal y al que todo ser humano intentaba imitar ${ }^{16}$. Con esta idea de perfección se comprende que se representara habitualmente a los monarcas llenos de vida, en plenitud de su fuerza. Si nos fijamos en las miniaturas que acompañan las el Códice Rico de las Cantigas de Santa María ${ }^{17}$, cuya composición en su versión final no llegó a terminarse, podemos observar que Alfonso $X$ queda siempre representado como un hombre activo, pese a que, por lo narrado en alguna cantiga, ya estuviera gravemente enfermo. Se podría aducir que semejante representación es el fruto de una propaganda monárquica de la época, pero si observamos las

\footnotetext{
15 Todos estos escritos tienen un punto en común $y$ es que han sido inspirados por los dichos de los sabios. Según la tradición, por ejemplo, el Secretum Secretorum habría sido obra de Aristóteles, que lo tradujo de una obra anterior, para su alumno Alejandro Magno, cuando éste ya había emprendido sus campañas militares. Los espejos y otros bocados contienen la sabiduría que los sabios han adquirido por experiencia propia o por su propia lectura e investigación. Pero para el receptor esa experiencia se ha transformado en un exemplum, es el fundamento de un didactismo que se basa en la noción del auctoritas, en la superioridad moral e intelectual del autor del escrito.

${ }^{16}$ G. DUBY, Le temps des cathédrales, París, 1976, p. 21.

17 Alfonso X, Cantigas de Santa María, Biblioteca de El Escorial, T.I.1 y Biblioteca Nacional, Florencia, B.R. 20.
} 
representaciones idealizadas del siglo XIX, e incluso del XX, vemos que el monarca suele ser joven, fuerte y mesurado, incluso en tiempos de crisis. Tales son los aspectos que, en los manuales escolares por ejemplo, expresan las realizaciones idealizadas de reyes como Fernando III, Luis IX de Francia o Jaime I.

A ello hay que añadir una dimensión puramente política que queda inscrita en los objetos, considerados ya como símbolos del poder, con los que se suele representar a los reyes.

El soberano, rey o emperador, suele llevar la corona, el manto, el cetro y la poma, a los que se añaden a veces un libro y una espada. Aunque Alfonso $X$ rara vez queda representado con todos estos atributos, insistiendo más en otros. Su representación más hierática la encontramos en el Libro de los Dados ${ }^{18}$, donde se nos presenta de frente, inmóvil. Aquí, el rey no es sólo un personaje, es una fuerza institucional y sobre todo moral, puesto que, como lo indica Isidoro, actúa con rectitud y por lo tanto muestra la buena conducta al resto de sus súbditos. Alfonso $X$ resume esta situación afirmando que

«el rey es cabeza del reino, pues así como de la cabeza nacen los sentidos por los que se mandan todos los miembros del cuerpo, bien así por el mandamiento que nace del rey, y que es señor y cabeza de todos los del reino, se deben mandar, y guiar y haber un acuerdo con él para obedecerle, amparar y guardar y enderezar el reino de donde él es alma y cabeza, y ellos, los miembros» ${ }^{19}$.

Sin embargo, aún queda por determinar cuales son los esquemas o los referentes que permiten determinar si una acción regia es recta o no y qué hace de ella una «ética, una teoría y una práctica del

18 AlfONSO X, Libro de Dados, Biblioteca de El Escorial, Ms. T.I.6, fol. $65 \mathrm{r}^{\circ}$.

${ }^{19}$ Siete Partidas, II, 1, 5, fol. 75r ${ }^{\circ}$. poder capaces de conservar la lealtad de los súbditos» ${ }^{20}$. Isidoro nos da una primera respuesta recordando que cuando los reyes dejan de actuar como se espera de ellos, dejan de ser reyes para convertirse en tiranos, es decir «reyes depravados e inicuos que ejercían sobre el pueblo un ansia desmedida de dominación y una autoridad sumamente cruel» ${ }^{21}$. Alfonso $X$ se explaya mucho más al definir al tirano

«como señor que es apartado en algún reino o rey en tierra por fuerza, o por engaño o por traición y estos atales son de tal natura que después que son bien apoderados en la tierra aman más de fazer su pro, maguer sea daño de la tierra que la pro comunal de todo porque siempre viven a mala sospecha de la perder. E por que ellos pudiesen complir su entendimiento más desenbargadamente dixieron los sabios antigos que usaron ellos de su poder siempre contra los del pueblo en tres maneras de artería. La primera e en que estos tales punan que los de su señorío que siempre sean necios y medroso porque quando tales fuesen no osarían levantarse contra ellos no contrastar sus voluntades. La segunda a los del pueblo que hayan desamor entre sí de guisa que no se líen unos de otros. Ca mientras en tal desacuerdo vivieren no osaran fazer ninguna fable contra él por miedo que no guardarían entre sí fe ni poridad. La tercera es que pugna de los fazer pobres y de meter los atan grandes fechos que los nunca pueden acabar porque siempre hayan que ver tanto en su mal que nunca les venga a coraçon de cuidar fazer tal cosa que sea contra su señor. $Y$ sobre todo esto siempre pugnaron los tiranos de astragar los poderosos y de matar los sabidores»22.

Son varios los elementos que nos proponen estas frases y que iremos evocando más adelante, pero por el momento tenemos que retener la idea de que el tirano es aquél que se apodera de la tierra, es decir, que gobierna sin derecho. Contraria-

\footnotetext{
${ }^{20}$ J. NiETO SORIA, Fundamentos ideológicos del poder real en Castilla, Mardid, 1988, p. 36: «una ética, una teoría y una práctica del poder, capaces de mantener la lealtad de los súbditos».

${ }^{21}$ Etimologias, IX, 3, 20.

22 Siete Partidas, II, 1, 10, fol. 76r ${ }^{\circ}$.
} 
mente al tirano, el rey, como lo indican las Siete Partidas, es vicario de $\operatorname{Dios}^{23}$, y por lo tanto recibe la tierra como una encomienda para regirla en $\mathrm{Su}$ nombre ${ }^{24}$. Evidentemente, el campo léxico del término vicario, y su relación con el mandato divino, nos remite al ámbito espiritual, y Alfonso $\mathrm{X}$ no tiene reparo en recordar que «en el tiempo de los gentiles el rey no tan solamente era guiador y caudillo de las huestes y juez sobre todos los del reino, mas aún era señor sobre las cosas espirituales». Aquí el rey castellano está haciendo referencia al origen divino de la monarquía ${ }^{25}$ ya que, según la Biblia, «tanto el poder político como el eclesiástico eran emanaciones de Dios» ${ }^{26}$. Sin embargo, y pese al espaldarazo divino, la monarquía parece ser esencialmente el fruto de una necesidad humana.

${ }^{23}$ Siete Partidas, II, 1, 5, fol. $75 \mathrm{r}^{\circ}$ : «vicarios de Dios (...) cada uno en su reino, puestos sobre las gentes para mantenerlas en justicia y en verdad en cuanto a lo temporal, bien así como el emperador en el imperio».

${ }^{24} \mathrm{Ibid}$., fol. $76 \mathrm{v}^{\circ}$ : «vicarios llaman aquellos ofiçiales que fican por los adelantados en lugar delos enperadores et de los reyes et delos grandes señores en las provinçias et en los condados (...) quando ellos no pueden y ser personalmente».

${ }^{25}$ F. FERNÁNDEZ CONDE, La religiosidad medieval en España, Gijón, 2005, p. 51-52: «El origen del poder político es teocrático. Como vicarios de Dios en la tierra, al servicio de la causa del reino y de la iglesia, sus actividades, inspiradas por la providencia divina, se convierten siempre en salvíficas, y su talante moral aparece adornado por sus biógrafos con virtudes excelentes, que los convierten en personas admirables, aunque la jerarquía eclesiástica nunca pretendiera canonizar a ninguno de ellos. En última instancia, semejante construcción ideológica servía, al mismo tiempo, para legitimar y fortalecer las relaciones de dependencia feudal entre el soberano y sus súbditos. Si Dios confería a los reyes los dominios terrenales como una especie de encomienda, por la que le debían respeto y servicios, estos, al margen de las relaciones de tipo socioeconómico, quedaban legitimados también para hacer lo mismo con la nobleza y el pueblo».

${ }^{26}$ J. NiETO SORIA, ob. cit., p. 47: «tanto el poder político como el eclesiástico eran emanaciones de Dios».
Isidoro de Sevilla ya nos recordaba que, entre los griegos, el rey es denominado Basileis, como base del pueblo ${ }^{27}$, es decir, que no parece tener nada que ver con la cúspide de una pirámide social. De hecho, la tradición judeocristiana presenta la monarquía como emanación de la voluntad popular, y no de una imposición personal de una casta particular. Según la Biblia el primer rey, a petición del pueblo para ser regido según la voluntad del Creador, fue Saúl, ungido por Samuel $^{28}$. Por lo tanto, el rey no nace en principio por voluntad divina, sino que es una concesión que Dios haría a sus fieles, para guiarlos hacia É $\mathrm{l}^{29}$. La misión del soberano es pues una misión de guía, es sin duda esa cabeza de reino que describía Alfonso X para intentar, en la medida de los posible, instaurar un reflejo de la Jerusalén celeste en la tierra. Y puesto que la monarquía es un don divino, ello significa que no todos los pueblos pueden pretender tener tal dignidad.

Alfonso X lo expone en sus Cantigas de Santa María ${ }^{30}$, cuando nos habla del buen rey David (ctg. 6, v.3) o de su hijo Salomón como dechado de virtudes (ctg. 382). Aquí el rey castellano parece querer romper la identidad nacional de estos personajes. No son percibidos como judíos sino como reyes del pueblo elegido, son la prueba de la fidelidad del pueblo hebreo hacia Yahvé que les otorga protección y victorias sobre sus enemigos. Pero, evidentemente, el panora-

${ }^{27}$ Etimologías, IX, 3, 18.

${ }^{28}$ I. SAMUEL 8-10.

${ }^{29}$ Y. SASSIER, Royauté et idéologie au Moyen Âge, París, 2002, p. 28-29: «La tradition vétérotestamentaire est porteuse d'une croyance en une relation directe et exclusive entre la divinité et le peuple Hébreu.... Telle est, dans la tradition vétérotestamentaire, la première vision d'une royauté fondée, non sur la volonté divine, mais sur une simple concession de Dieu au désir du peuple de se donner un maître».

${ }^{30}$ Para las referencias textuales utilizaremos la edición de W. METTMAN, Castalia, 1989. 
ma ha cambiado con el Nuevo Testamento, puesto que, según los cristianos, el pueblo elegido se aparta del camino divino al rechazar a Cristo como Mesías, y pierde por lo tanto su relación privilegiada con Dios. La consecuencia más directa de este rechazo sería para los hebreos la pérdida de su rey y de su tierra. La monarquía era pues percibida como una institución que manifestaba la fe viva de un pueblo, era la encarnación de la protección divina hacia los fieles. Aunque esta teoría plantea el problema de situar los soberanos musulmanes.

Como indicaba antes, las Cantigas de Santa María muestran varios reyes, cristianos y musulmanes, sin auténtica diferencia entre ellos. $\mathrm{Y}$ en los diferentes escritos alfonsíes, no encontramos expresiones de rechazo de las monarquías musulmanas. Éstas quedan descritas como los enemigos de Cristo por seguir la secta de Mahoma, pero en ningún momento encontramos una acusación que niegue a los monarcas del sur su derecho al trono. De hecho, si comparamos las representaciones iconográficas de las monarquías cristianas y musulmanas, tal y como nos las proponen las Cantigas de Santa María, observamos que no hay auténticas diferencias. Las miniaturas de la cantiga 169 nos muestran justamente tres representaciones idénticas de un rey musulmán y dos cristianos, sentados en un nivel superior al resto del público, en un espacio delimitado de la escena, puesto de realce por las volutas de la arquitectura y por supuesto coronados.

Esta similitud se explica en realidad por el comportamiento específico atribuido a los monarcas musulmanes.

El enemigo de la fe cristiana queda personificado en la colección de milagros instigada por Alfonso X por el Moro invasor, lo que podría dejar suponer que los poemas alfonsíes son el producto del espíritu de cruzada de los siglos XII y XIII. Al igual que los monarcas cristianos, los musulmanes luchan entre sí, sin olvidar su oposición al infiel cristiano. La guerra es el marco histórico en el que ocurren los milagros marianos, pero esta vez la Virgen acepta en ocasiones una tregua con su enemigo tradicional.

En el poema 181, Umar-al-Mutada (1248-1266) obtiene la protección de la Virgen contra Abu Yusuf Ya'kub. La narración del poema nos recuerda el asedio de Abu Yusuf Ya'kub contra «un rei» (v 7) en la «cidade de Marrocos» (v 6). El monarca asediado no queda mencionado y la datación histórica no puede hacerse sino por la referencia a la campaña marrueca del sultán de Fez y al río de Umm Rabî̀. El silencio del poeta sobre la identidad del rey musulmán crea la ilusión de que es un soberano cristiano asediado por un musulmán. Sin embargo, el verso 41 rompe esta ilusión puesto que el poeta nos indica que María ayuda a sus amigos, aunque sean de otra ley ${ }^{31}$. El desenlace llega cuando el rey moro acepta los consejos de los cristianos de la ciudad y expone una estatua de la Virgen en el campo de batalla para vencer a su enemigo.

La semejanza entre los reinos musulmanes y cristianos se refuerza con la referencia al sultán de Siria (ctg. 28). El nombre del personaje queda omitido, pero el Moro conserva su dignidad puesto que es identificado como rey, pese a quedar acompañado por una horda de paganos ${ }^{32} \mathrm{y}$ ser de la ley de Mahoma ${ }^{33}$. La conversión al cristianismo del sultán, que actúa entonces como un hombre sabio (v. 118), aumenta su dignidad como dirigente caracterizado por una sabiduría especial haciendo de él un ejemplo vivo para sus semejantes.

\footnotetext{
${ }^{31}$ Ctg. 181, v. 41: «assi Santa Maria ajudou a seus amigos, // pero que d'outra lei eran, a britar seus êemigos».

${ }^{32}$ Ctg. 28, v. 17 : «oste de paganos».

${ }^{33}$ Ctg. 28, v. 91: «o falsso connoçudo».
} 
El rey musulmán no parece ser despreciado, aunque sea el enemigo religioso y político de los cristianos. El poema 165 nos habla de Baybars I (1273-1302) cuando asedió Tartus (1270-1271). El primer sultán de Egipto representa aquí la oposición a los cruzados $^{34}$ y queda descrito como un hombre que odiaba el cristianismo por encima de todo $^{35}$. Sin embargo, también se le describe como un hombre piadoso que cree en su propia fe. Así cuando asiste a la aparición de la Virgen, reconoce su santidad como se lo enseña el Corán ${ }^{36}$.

De la misma forma, cuando organiza una incursión contra los cristianos, el rey de Granada, Abu Abdallah (1273-1302) considera une locura enfrentarse contra los devotos de Maria ${ }^{37}$. Su respeto por la Virgen y por las creencias personales de Alfonso X, se confirma cuando envía al rey castellano una estatua que no a podido ser destruida (ctg. 215). Por este gesto, el rey musulmán reconoce el poder de Maria y, sin convertirse al cristianismo, demuestra su capacidad de juicio, es decir, su sabiduría.

Todos estos relatos, que sin duda son el fruto de la cultura y la propaganda cristiana de la época, muestran, sin embargo, que la esencia de la realza sobrepasa el simple marco de la cristiandad y adquiere une carácter universal. La monarquía forma una fraternidad, dividida por las voluntades políticas y los errores religiosos, pero que siempre puede reconciliarse por la sabiduría que reside en sus miembros y que, desde el punto de vista alfonsí, se manifiesta por el respeto a la Virgen.

\footnotetext{
${ }^{34}$ Ctg. 165, v. 12-13: «guerrejar // quería sempr'a crishãos / e fazer-lles muito mal».

${ }^{35}$ Ctg. 165, v. 7-8: «cruel // e porend'aos crishaos / desamava mais que al».

${ }^{36}$ Azora III, v. 37 y siguientes; Azora XIX, v. 22.

${ }^{37}$ Ctg. 185, v. 86-87: «e teerm-m-ia por fol//sse contra Maria fosse que os seus defender sol».
}

$\mathrm{Y}$ es que, pese al aspecto aparentemente político y laico de la realeza, no se puede soslayar la influencia divina sobre la que se fundamenta su capacidad de gobierno, y que las Cantigas de Santa María nos recuerdan insistentemente afirmando que la voluntad de los reyes está entre las manos de Dios $^{38}$, con una clara alusión al libro de los Proverbios ${ }^{39}$. Esta influencia es aún más evidente si, amparándose en las historias de Saúl, y más tarde de David y Salomón, el monarca tiene primero que recibir un signo que lo identifique como el elegido de Dios, siendo ungido por un sacerdote ${ }^{40}$ que, según Isidoro de Sevilla, es aquél que «da lo sagrado» ${ }^{41}$. Estamos tocando aquí un punto clave en la civilización occidental que va a motivar, a lo largo de varios siglos, enfrentamientos políticos y militares con el fin de determinar la relación de ascendencia o de vasallaje que deben entretener entre sí la monarquía, o la dignidad imperial, y la Iglesia. Esta relación queda plasmada en la imagen acuñada por Gelasio I, cuando describió estas dos instancias como dos espadas que debían servir a Dios, y retomada por Alfonso $X$ al recordar que «dixieron los sabios que el enperador es vicario de Dios en el imperio para fazer iustiçia en lo

\footnotetext{
${ }^{38}$ Ctg. 382, v. 4-5: «Verdad'éste a paravoa que disse Rey Salomon // que dos reys as voontades enas máos de Deus son».

39 Proverbios, 8, 15-16: «Por mí reinan los reyes, y los príncipes decretan lo justo. Por mí mandan los jefes, y los nobles juzgan la tierra».

${ }^{40}$ Y. SASSIER, ob. cit., p. 121: «le recours au sacre a une finalité précise conférer (...) cette légitimité qu'il ne peut revendiquer par ses ancêtres. Comme les onctions pratiquées au VIIe siècle en Espagne, l'onction trouve son inspiration dans le premier livre des Rois (de Samuel) qui montre Samuel versant le chrême sur la tête de Saül, le premier roi hébreu, puis sur celle de David, son successeur. (...) dans le récit biblique, l'onction est aussi investissement de l'âme du roi par L'esprit de Dieu, elle lui confère une inviolabilité personnelle».

${ }^{41}$ Etimologías, VII, 12, 17.
} 
temporal bien assí como lo es el papa en lo espiritual» ${ }^{42}$.

Sin embargo, Alfonso $\mathrm{X}$ parece haber mantenido con la Iglesia une relación muy diferente a la que expresa en sus Partidas, y por la cual, pese a haber sido elegido emperador de romanos, la dignidad imperial le fue negada por diferentes papas. Este rechazo se podría deber al recelo que Roma podía tener ante los Hohenstaufen y sus descendientes, entre los cuales se encontraba Alfonso $\mathrm{X}$. $\mathrm{Y}$ es que, sin llegar a expresarlo oficialmente, el monarca tenía un claro comportamiento gibelino que no podía más que inquietar al papado.

Como ya lo indicaba antes, la dignidad real queda estrechamente ligada a la elección divina, representada por la intervención del sacerdote que unge al rey. Sin embargo, Alfonso $X$ no fue coronado por ningún representante de la Iglesia, ya que se autocoronó ${ }^{43}$. Su ritual de coronación comportó esencialmente un reconocimiento por parte de sus vasallos al ser elevado sobre la tumba de sus antepasados. Como lo indican Salvador Martinez ${ }^{44}$ y Gonzalez Jimenez ${ }^{45}$, la tradición castellana, comparada con la francesa por ejemplo, era mucho más sencilla puesto que no comportaba realmente una ceremonia religiosa, como la que acompañó la subida al trono de Luis IX de Francia ${ }^{46}$. Al cumplirse el reconocimiento del nuevo rey al tiempo que se terminaba la ceremonia del sepelio de su predecesor, la sociedad castellana establecía que el derecho a la corona procedía «del heredamiento y se trasmitía por derecho sucesorio de

\footnotetext{
42 Siete Partidas, II, 1 , fol. $74 \mathrm{v}^{\circ}$

${ }^{43}$ LuCAS DE TUY, Crónica de España, edición de J. PUYOL, Madrid, 1926, p. 449-450.

${ }^{44}$ H. SAlvador MartíneZ, Alfonso X, el sabio. Una biografía, Madrid, 2003, p. 113-117.

${ }^{45}$ M GONZÁLEZ JIMÉNEZ, Fernando III el santo, Sevi1la, 2006, p. 44-45.

${ }^{46}$ J. LE GOFF, Saint Louis, París, 1996, p. 98.
}

padre a hijo» ${ }^{47}$. Esta legalidad en la forma de obtener y conservar la corona da al monarca cierta superioridad con respecto al emperador, puesto que, como lo recuerda Alfonso $X$, los reyes «tienen el señorío por heredad, lo que no pueden hacer los emperadores que lo ganan por elección» ${ }^{48}$. Sin embargo, aún le quedaba por demostrar a Alfonso $X$ que no era un tirano, es decir, que no había obtenido la corona por fuerza o con engaño y que gobernaba para el bien de sus súbditos.

La ausencia de una ceremonia religiosa no significa que la monarquía castellana rechazara $u$ olvidase su misión divina ${ }^{49}$. Prueba de ello es que Fernando III $^{50}$ terminó por ser canonizado en el siglo XVII, aunque ya en el siglo XIII empezaba a ser considerado como un santo. En efecto, la cantiga 292 nos relata la aparición de Fernando III en un sueño para transmitir un último mensaje a un orfebre y poder así donar uno de sus anillos a la Virgen. Dichas apariciones oníricas sólo eran posibles para los santos. Pero, para asentar el poder del rey sabio, «los teóricos de la concepción jurídica de Alfonso $X$ intentaron, seguramente, compaginar la tradición sagrada sobre los orígenes del poder, que dependía en última instancia de la teocracia bíblica (...) en las obras jurídicas del rey Sabio se

-

${ }^{47}$ H. SALVADOR MARTÍNEZ, p 114.

${ }^{48}$ Siete Partidas, II, 1,8 , fol. $76 \mathrm{r}^{\circ}$.

${ }^{49}$ A. RUCQUOI, ob. cit., p. 77.

${ }^{50}$ F. FERNÁNDEZ CONDE, ob. cit., p. 55: «La corona que se pone Fernando III en la cabeza no es más que un símbolo de su poder y de su soberanía real, utilizada, según el discurso ideológico de los escritores de su tiempo, para llevar adelante los planes de la Providencia. Pero esa soberanía era para ellos un don de la divinidad para cumplir su misión política y religiosa al mismo tiempo. Y sabían perfectamente que esa virtualidad sacra servía también para fortalecer su autoridad en el entramado de una sociedad compleja por la proliferación delos centros de poder local ejercidos por una poderosa nobleza, satisfecha únicamente cuando podía aumentar sus dominios a expensas de la lucha contra el Islam». 
registra ya una notable evolución secularizadora de la idea de estado» ${ }^{51}$. Y esta voluntad secularizadora se va construir sobre la noción de heredamiento que evocábamos antes, así como sobre todo un programa que apuntaba a demostrar primero que Alfonso $X$ había sido elegido directamente por $\operatorname{Dios}^{52}$, de quien había recibido la sabiduría necesaria para gobernar, y después que actuaba conforme al buen gobierno y no como un tirano.

Tal y como lo indicaba ya Nieto Soria, «una causa de sacralidad para la realeza castellana podía encontrarse en la consideración del linaje real como particularmente elegido por Dios para ser origen de los diversos monarcas, habiendo recibido tal linaje una continua protección divina para asegurar su preservación y evitar su interrupción, remontándose en todo caso su procedencia histórica a tiempos remotos, siendo esta antigüedad garantía de legiti$\operatorname{midad} »^{53}$.

No es pues extraño que Alfonso $X$ quisiera subrayar la nobleza de sus antepasados y la relación privilegiada que mantenían con los poderes celestiales, esencialmente representados por la Virgen María. Teniendo en cuenta que, contrariamente a la monarquía francesa por ejemplo, los monarcas castellanos rechazaban cualquier don taumatúrgico, Alfonso $\mathrm{X}$ va a insistir en los milagros que han favorecido a su familia, ya que «Dios y el milagro son elementos fundamentales del fenómeno legendario estando ambos muy presentes en cualquier concepción del poder real. La leyenda, en cuanto que es testimonio del milagro, lo es también del poder de protec-

-

${ }^{51}$ Ibid., p. 59

${ }^{52}$ G. MARTÍN, «Alphonse $X$ ou la science politique», Cahiers de linguistique hispanique médiévale, 18-19, 1993-1994, p. 12.

${ }^{53}$ J. NIETO SORIA, ob. cit., p. 65 : ción del protagonista de la misma» ${ }^{54}$. No es pues extraño que sean las Cantigas de Santa María las que nos propongan los ejemplos más claros de este programa de identificación del rey como protegido y elegido de la Virgen.

La cantiga 221 evoca la genealogía del rey y su relación con la Virgen. Alfonso VIII (1158-1214), bisabuelo del rey sabio, es una referencia a la victoria de las Navas de Tolosa, mientras que su esposa, Leonor, hija del rey Enrique II de Inglaterra establece una conexión política con las islas pero también con los milagros marianos que allí ocurrieron. Berenguela de Castilla es testigo en esta narración del milagro que hizo la Virgen al salvar al futuro rey santo. Su madre, llena de dolor ${ }^{55}$ sólo pudo recuperarse cuando fue sanado el futuro Fernando III por la Virgen de las Huelgas ${ }^{56}$ indicando así que el rey estaría siempre bajo la protección de María. Es una forma de señalar una relación privilegiada entre la Virgen y la familia real castellana, estableciendo así una elección divina que otorga el derecho al trono. Dicha elección debe perpetuarse en la persona de Alfonso X.

Este último no va a dudar en recuperar en beneficio propio, las hazañas y actos de sus antepasados. Así, la cantiga 361 nos propone una referencia explícita al rey «Don Alfonso de Castela, aquel que primeira vez vençeu o sennor dos mouros pola fe de Deus crecer» ${ }^{57}$. Se trata de una referencia directa a la victoria de las Navas de Tolosa, pero al mencionar únicamente al rey Alfonso de Castilla, bien se podría confundir a Alfonso VIII con Alfonso X. De hecho la filiación entre ambos queda evidenciada

\footnotetext{
54 Ibid., p. 39.

${ }^{55}$ Ctg. 221 , v. 33: «sa madre tornou tal come sandia».

${ }^{56}$ Ctg. 221, v. 56-57: «acorreu ao menyo e de ssa enfermedade lle deu saude conprida».

${ }^{57}$ Ctg. 361, v. $13-14$ :
} 
por su presencia en versos casi sucesivos ( $\mathrm{v}$ 13 / v 15). Más significativa aún, es que la evocación de las Navas no tiene ningún sentido o ninguna relación con el milagro que se narra aquí. El efecto es pues subrayar una continuidad, una identificación, en el seno de la familia, que redunda en favor de Alfonso X.

Desde luego, el conjunto de las referencias a Alfonso X en las Cantigas de Santa María tiene como objetivo recordar la piedad del rey, protector de las reliquias de María $^{58}$, constructor de catedrales ${ }^{59}$ y también como testigo directo de los milagros marianos. La protección de la que goza el rey se verifica contra sus enemigos ${ }^{60}$, pero también contra la muerte ${ }^{61} \mathrm{o}$ la enferme$\operatorname{dad}^{62}$.

El colofón podría ser entonces el poema 209, en el que se nos narra cómo, estando el rey gravemente enfermo ${ }^{63}$, sanó gracias al contacto directo del volumen de las Cantigas ${ }^{64}$. Puesto que se habla de un solo volumen, podemos suponer que es la primera versión de las tres que componen el conjunto mariano promovido por Alfonso X. El milagro descrito en el poema 209 trasforma el manuscrito en un auténtico objeto taumatúrgico, en una reliquia que, sin haber estado en contacto con María, permite que se manifieste su poder. La importancia de la participación del rey en la redacción de las Cantigas de Santa María se resume en que las otras obras alfonsinas no han protagonizado ninguna manifestación divina. Las Cantigas de Santa María se trans-

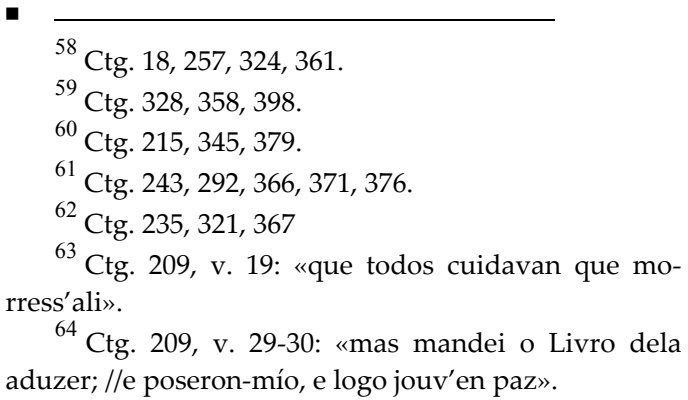

forman en un libro único, casi en una Biblia y por lo tanto Alfonso X, al dar esta reliquia a sus semejantes, rebasa el papel del monarca que da la ley ${ }^{65}$ y se presenta como un auténtico sacerdote, en le sentido isidoriano del término,

De ahí a decir que todo lo que hace el rey tiene la bendición divina, sólo hay un paso.

Una vez demostrada la protección divina de la que gozaba el soberano, quedaba por demostrar que dicha protección era merecida, y que Alfonso $X$ no era un tirano. Si nos referimos al comportamiento del tirano y lo tomamos como la antítesis de lo que ha de hacer un buen rey, éste ha de procurar que sus súbditos tengan acceso al conocimiento, que puedan vivir en armonía, que participen en proyectos para el bien común y sobre todo en una sociedad donde no se persiga a los sabios. Las acciones justas del monarca que evocábamos al principio de esta reflexión parecen pues orientarse a la unificación de la sociedad caracterizada por la divulgación del saber y el respeto del sabio.

La unificación de la sociedad y la divulgación del saber son dos aspectos que quedan estrechamente unidos en la producción alfonsina. En los prólogos de sus obras, siempre aúna la idea de pertenencia a un mismo reino, con la consabida enumeración de las posesiones reales y sobre todo con el establecimiento de una ley común, las Siete Partidas, redactas a pro comunal ${ }^{66} \mathrm{y}$ en castellano para que todos los de su reino puedan tener acceso a ella. Qué duda cabe que la utilización del castellano, como lengua oficial del reino, es un modo de favorecer la divulgación del conocimiento, pero lo que realmente demuestra la voluntad del monarca de presentar una formación gene-

\footnotetext{
${ }^{65}$ G. MARTÍN, ob. cit., p. 6

${ }^{66}$ Siete Partidas, I, fol $3 \mathrm{r}^{\circ}$.
} 
ralizada de sus súbditos es que su producción abarca todos los temas que pueden interesar al individuo, desde la legislación hasta la espiritualidad, pasando por la ciencia y la historia. Además, a cada tipo de producción se le atribuye un papel o una misión específica, no se trata de un conocimiento teórico, sino que cada tema tiene una «finalidad directa y práctica en su aplicación cotidiana a los múltiples problemas de un gobierno que se propone alcanzar en teoría insospechados niveles de autoridad y eficacia ${ }^{67}$. La ley ha de servir para vivir en armonía, la historia para no cometer los errores del pasado ${ }^{68}$, la literatura religiosa para salvar el alma, los escritos morales y lúdicos para dar un referente moral y un comportamiento razonado a cada individuo y por último los libros de ciencia o de astromagia para modificar o prever los acontecimientos que han de llegar. Todo ello redactado en lengua vernácula para que todos, sin importar la religión practicada, pudieran acceder al conocimiento. El conjunto de las obras promovidas por el rey demuestra que, como lo indica el prólogo del Libro de las estrellas, Alfonso $\mathrm{X}$ quiso rescatar, remozar y divulgar la sabiduría del pasado para que cada cual pudiera usarla y así mejor juzgar su relación con el resto de la Creación.

Ahora bien, la lectura y el descubrimiento, el hecho de ser sabidor de algo, no son suficientes para ser sabio. Si algunos escritos, como los historiográficos, los legislativos o los lúdicos, parecen orientarse hacia la obtención del entendimiento necesario al sabio, otros, esencialmente los de astromagia, han de ser utilizados únicamente por aquellos que ya poseen cierto conocimiento y la sabiduría suficiente para no caer en la tentación de utilizar su poder

${ }^{67}$ F. MÁRQUEZ VILlanUEVA, ob. cit., p. 32.

${ }^{68}$ AlFONSO X, Estoria de España, Biblioteca de El Escorial, Ms. Y-I-2, fol. $2 \mathrm{r}^{\circ}$. y siguientes. para oprimir a sus semejantes. Es lo que nos indica el prólogo del Lapidario ${ }^{69}$ que aconseja al lector ser sabidor de astronomía, de gemología y de medicina con el fin de utilizar correctamente los secretos que en el manuscrito se pueden hallar.

Nos encontramos pues con la idea de una progresión, que va acercando el individuo a los ángeles, que va haciendo de él un sabio, y por lo tanto un santo. En esta progresión se entiende que Alfonso X es un rey de reyes porque conoce la historia y sus enseñanzas, porque conoce el secreto de los planetas y de las piedras, porque tiene la bendición divina. En resumidas cuentas, Alfonso $\mathrm{X}$ es un rey sabio porque conoce la ciencia de los hombres y de Dios y sabe aplicarla para el bienestar de sus súbditos. Todo ello va a quedar plasmado en la miniatura de presentación del Códice Rico.

En una composición iconográfica clásica, inspirada por el concepto gelasiano del poder que indicaba antes, se suele encontrar a Cristo en el centro de la imagen y a su diestra el representante de la Iglesia, el Papa o un obispo, mientras que en el lado opuesto se encuentra el representante del poder terrenal, el rey o el emperador ${ }^{70}$. Cuando el personaje central es el emperador o el monarca, siempre se encuentra a su diestra el representante religioso. Los personajes siempre están de frente, con una

\footnotetext{
69 Alfonso X, Lapidario, Biblioteca de El Escorial, Ms. H.I.15., fol. $1 v^{\circ}$.

${ }^{70}$ R. JACOB, Images de la justice, París, 1994, vol 1, p. 25 : «le pouvoir spirituel occupe toujours la gauche de l'image, donc la droite du Christ, tandis que le temporel lui fait pendant du côté opposé. A la présence symbolique de l'ordre spirituel, il n'y a guère d'exception. Par ailleurs, le pape et l'empereur peuvent céder la place à d'autres personnages, un évêque et un roi par exemple, pourvu que les deux pouvoirs soient clairement identifiés à travers leurs attributs emblématiques (...) Aussi les illustrateurs prennent-ils souvent le parti d'effacer la personne du Christ, ne laissant en présence que les chefs charismatiques des deux pouvoirs»
} 
forma hierática que ya vimos en la imagen de presentación del Libro de dados y que se repite en la General Estoria ${ }^{71}$, aunque aquí ya vemos uno de los rasgos esenciales de la representación pictórica de Alfonso X. Como lo indicó Rafael Cómez Ramos, la representación en tres cuartos es novedosa ${ }^{72}$ si exceptuamos la Biblia de Toledo y la imagen de Luis IX de Francia que en ella podemos observar.

Esta posición permite dar mayor profundidad al personaje y desde luego, representarlo más como un hombre que como una institución. Lo que se nos está mostrando aquí es otra dimensión del personaje regio. Los símbolos del poder quedan relegados a un segundo plano, e incluso son alterados, ya que aquí el libro cerrado suele ser reemplazado por un pergamino que se está redactando ${ }^{73}$. Todo ello se ve en la miniatura que abre la Primera Partida ${ }^{74}$ en la que aparece el monarca como un legislador, dirigiendo la redacción del libro bajo la mirada del Creador. El rey y sus escribas parecen estar en un mismo plano, pictórico y humano, ante la presencia del Creador

${ }^{71}$ Alfonso X, General Estoria, Biblioteca Vaticana, Ms Urb. Lat. 593, fol. 2v.

${ }^{72}$ R. COMEZ RAMOS, «El retrato de Alfonso X el sabio, en la primera Cantiga de Santa María » in J. KATS y J. KELLER, Studies on the Cantigas de Santa María Madison, Hispanic Seminary of Medieval Studies 1987, p. 37: «No hay imágenes con semejantes características en toda la miniatura europea del siglo XIII. Tan sólo podemos establecer un parangón con el retrato de Luis IX de Francia en la Biblia de la Catedral de Toledo».

${ }^{73}$ Ibid., : «el retrato está realizado en tres cuartos, lo cual acentúa aun más la expresión del mundo interior del monarca. Aun cuando aparece con toda dignidad y majestad, el interés del artista se concentra en la persona representada y no en sus prerrogativas de poder. Si el retrato es una evocación de ciertos aspectos de un ser humano particular, visto por otro, aquí nos encontramos ante la más acabada visión de la personalidad del rey poeta, del rey sabio».

${ }^{74}$ Alfonso X, Primera Partida, Londres, British Library, Ms. add. 20.787. fol. $1 v^{\circ}$ considerado como «comienzo y medio y acabamiento de todas las cosas» ${ }^{75}$.

Con algún detalle diferente observamos casi la misma organización en El libro de las Formas e Imágenes que están en el cielo $^{76} \mathrm{o}$ incluso en la letrina que inicia el Lapidario $^{77}$. El Lapidario vuelve a proponernos una composición doble, casi como la de las Siete Partidas, aunque esta vez Dios ha sido remplazado por un filósofo. La letrina que inicia el libro ha de ser analizada junto a la imagen de Aristóteles que se encuentra inmediatamente encima y cuya proximidad y similitud en la composición y el ademán de los personajes sugeriría, según Marta Lacomba, que Alfonso X estaba colocando su producción bajo el patronato e inspiración del más cumplido de los filósofos ${ }^{78}$.

En cierta medida, la imagen de presentación de las Cantigas de Santa María, en el Códice de los Músicos o en el Códice Rico, se inscribe perfectamente en esta serie de imágenes en la que el monarca se caracteriza por estar en contacto directo con el libro y con los que lo producen ${ }^{79}$. Sin embargo, recordando que la realeza es también un sacerdocio, hay que recalcar unas diferencias significativas que hacen de la miniatura del Códice Rico una composición totalmente diferente en el plano político y espiritual.

El monarca sigue ocupando el centro de la escena, lo que no deja de ser paradóji-

${ }^{75}$ Siete Partidas, Prólogo, fol. $1 \mathrm{v}^{\circ}$.

${ }^{76}$ ALFONSO X, Libro de las Formas e Imágenes que están en el cielo, Biblioteca de El escorial, Ms. H. I. 16, fol. $1 v^{\circ}$.

${ }^{77}$ Lapidario, fol. $1 \mathrm{v}^{\circ}$.

${ }^{78} \mathrm{M}$. LACOMBA, Image du savoir, image du pouvoir dans le Lapidaire, e-Spania, 2007, http://espania.revues. org/document144.html, § 19-20.

${ }^{79}$ A. DOMÍNGUEZ RODRÍGUEZ, «La miniatura en el scriptorium alfonsí», J.MONTOYA y J. MONDEJAR, Estudios Alfonsíes, Granada, 1985, p. 144: «La imagen de dedicación o presentación del códice lleva implícito el ofrecimiento del mismo por el copista, traductor o autor de la obra al soberano que la patrocinó». 
co en una composición que se dedica a la Virgen. Queda, además, puesto de realce al estar situado justo encima del intercolumnio. Por otra parte, si observamos la distribución de los personajes, sobre todo en la imagen del Códice Rico, y la comparamos con las miniaturas de orden puramente político, observamos una estructura muy peculiar.

Primero, a la diestra del monarca no se encuentra realmente el religioso, sino un escriba que parece llevar tonsura. Tiene una relación con la Iglesia, pero desde un punto de vista cultural e intelectual y no espiritual. Como punto de comparación recordemos que en la Biblia de Toledo, el religioso está del mismo lado que la reina, como representante del poder establecido, mientras que el escriba está del lado del joven rey al que se está educando. En el Códice Rico, la actividad intelectual queda estrechamente ligada a la monarquía alfonsina que, sin embargo, no rechaza el aspecto espiritual de la misma.

En lo que respecta la distribución espacial, hay similitudes con los demás manuscritos. Suelen mostrar los escribas ofreciendo el libro al rey que señala un pasaje con su dedo. Con este gesto se nos está indicando que la sabiduría se transmite tanto por la palabra hablada como por la palabra escrita ${ }^{80}$. Las proporciones entre el rey y los demás personajes no parecen muy diferentes, pero el monarca se encuentra en un trono a la turca de forma que está por encima de su público ${ }^{81}$. Es así como se representa, en la Edad Media, al maestro, al que trasmite la sabiduría y cuya mejor imagen es la de Aristóteles en el Lapidario.

\footnotetext{
${ }^{80}$ R. JACOB, ob. cit., vol II, p. 170: «dans ces scènes l'autorité se transmet à la fois par la parole, par le livre et par le geste de l'index du maître qui tout à la fois communique son savoir et commande l'obéissance».

${ }^{81}$ J. GLEnISSON, Le livre au Moyen Age, Turnhout, 1988 , p. 247.
}

La idea de transmisión queda también expresada por los personajes que salen de los espacios limitados por las columnas, sus vestidos se tocan. En el Lapidario, Aristóteles no está separado del público, las columnas dibujadas sólo sirven para dar profundidad a la escena. Lo mismo ocurre en la Estoria de España ${ }^{82}$ o en la General Estoria $^{83}$, donde observamos una organización parecida a la de las Cantigas de Santa María. La escena está dividida en cinco partes por las columnas, y el rey está rodeado por ocho nobles. Ello nos demuestra que el artista podía distribuir las masas presentes de forma equilibrada. Por otra parte es evidente que el monarca comparte el mismo espacio, la misma sala, que sus cortesanos. Pero en el Códice Rico, la composición es muy diferente. El arco central es mayor y queda adornado por un velo, poniendo así de realce un espacio diferente del resto de la sala. El rey está aislado, rodeado por otro espacio en el que hay sólo unos cuantos elegidos. A su vez, los escribas están separados de los músicos por unos velos, delimitando así un tercer espacio en el que hay más ruido y más movimiento. El brazo del músico de la izquierda así como las extremidades del asiento real escenifican el paso de un espacio a otro demostrando que, pese a la reducción de los presentes, sigue habiendo una posibilidad de comunicación entre los espacios y sus ocupantes.

Por otra parte, las imágenes del Códice Rico y del Códice de los Músicos nos muestran un número diferente de músicos. Ello demuestra que la representación no es real, no intenta indicar el número de instrumentos o de voces que debían participar en la polifonía de las Cantigas de Santa María. Es una representación simbólica del mundo y del proyecto alfonsí.

\footnotetext{
${ }^{82}$ Estoria de España, fol. $1 \mathrm{v}^{\circ}$.

${ }^{83}$ General Estoria, fol. $2 \mathrm{v}^{\circ}$.
} 
Según la representación del Códice Rico, vemos a lo lejos una ciudad, lugar exterior de bullicio. Después hay un espacio en el que se mueve un pequeño grupo que no puede pasar al espacio siguiente donde sólo acceden unos pocos colaboradores directos del monarca. Pero estos elegidos quedan fuera del espacio reservado al rey sabio. Las Cantigas de Santa María nos proponen pues la única organización tripartita del espacio relacionado con Alfonso X. Esta organización, marcada por el número de personas y por la presencia de los velos, parece plasmar la evolución que debe seguir el individuo para conseguir la sabiduría. En un contexto más religioso, esta organización se puede asemejar a la de un templo, lo que no es extraño si tenemos en cuenta el tema religioso del manuscrito. $\mathrm{Y}$ por supuesto el paradigma de los templos es el del rey Salomón. Según la Biblia el templo presentaba un primer vestíbulo (ulam), por el que se accedía a la casa central (hecal) donde se situaba el Sancta Santo- rum (debir) aislado del resto del mundo por un velo «de jacinto, de púrpura, de escarlata y de lino, en el cual [Salomón] hizo dibujar querubines» ${ }^{84}$.

En un ámbito puramente religioso, esta división debía conducir el creyente hacia Dios, pero en las Cantigas de Santa María, le lector se encuentra con la imagen del monarca, que está dando lo sagrado, puesto que está dirigiendo la creación de la composición poética por la que se manifestó María. Nos encontramos pues con una representación de la Sabiduría hecha hombre y que puede, por lo tanto, ser considerado como santo al alcanzar un alto nivel en la jerarquía celestial descrita por el rey castellano. La sabiduría y la fe religiosa quedan así personalizadas y unificadas en un solo monarca, en un rey-sacerdote, cuya ambición fue ser reconocido como trovador de la Virgen y al que la Historia ha otorgado el merecido título de Sabio.

${ }^{84} 2$ Paralipomenos 3, 3-17. 